\title{
Analysis of Sexual Function in Women During the Trimesters of Pregnancy: A Cross-Sectional Study
}

\author{
Moretti $\mathrm{E}^{1}$, Barbosa $\mathrm{L}^{2}$, Nascimento $\mathrm{T}^{2}$, Carvalho ICS ${ }^{2}$ and Boaviagem $\mathrm{A}^{2}$ \\ ${ }^{1}$ Physical Therapy Department, Federal University of Pernambuco, Brazil \\ ${ }^{2}$ Physical Therapy Department, Faculdade Estácio do Recife, Brazil
}

Submission: December 21, 2016; Published: May 05, 2017

*Corresponding author: Alessandra Boaviagem, A. PT, MSc, Physical Therapy Department, Faculdade Estácio do Recife, Brazil, Email: alessandraboaviagemf@gmail.com

\section{Introduction}

Pregnancy is a period in which a woman's body undergoes changes, with distinct characteristics in each trimester [1]. These changes often involve musculoskeletal, hormonal and psychosocial adaptations that affect a woman's quality of life. In this respect, changes in sexual response (phases of desire, arousal, orgasm and resolution) may lead to a decline in selfesteem, in addition to compromising social relationships [2-5].

The first trimester of pregnancy is marked by an increase in human chorionic gonadotrophic (HCG) hormone production, responsible for sustaining the pregnancy and the emergence of nausea, sleepiness, fatigue and mood swings. Moreover, it increases mammary volume and may cause local hypersensitivity and discomfort, potentially reducing the frequency of sexual relations [6-8]. During this period, the resolution phase is slower, which leads to residual vascular, vulvar and vaginal obstruction capable of lasting for hours after sexual activity [6,9].

HCG production declines during the second trimester, whereas progesterone and estrogen rates rise gradually, making women better adapted to pregnancy [8]. In this phase of pregnancy, there is an increase in pelvic congestion and a reduction in the symptoms present in the first trimester. The absence of these symptoms may therefore contribute to more frequent sexual relations $[6,7,10]$.

The third trimester is characterized by an increase in anxiety with the approaching delivery and rise in abdominal volume, causing physical discomfort and hindering sexual intercourse. As such, a decrease in the frequency of sexual relations may occur during this period $[7,11]$. By contrast, there is a considerable increase in vaginal lubrication and a prolonged resolution phase, both greater than in the first and second trimesters [6].

In this respect, any factor that interferes in the phases of the sexual response cycle is capable of compromising the sexual performance of pregnant women, resulting in dysfunctions $[4,8,11]$.
These dysfunctions can be classified as follows:

a) "Sexual desire and arousal disorder", which occurs when there is an absence or decline in sexual desire and/or vaginal lubrication.

b) "Sexual pain disorder", characterized by vaginism or dyspareunia.

c) "Orgasm disorder", when there is a delay or absence of orgasm [11-13].

Furthermore, sexual response can also be influenced by age, smoking, parity, schooling level, clinical instabilities and chronic diseases $[14,15]$. As such, given that sexuality is an important factor that interferes directly in the quality of life of individuals, the present study aimed at analyzing the sexual function of women in each trimester of pregnancy in order to identify the frequency of sexual dysfunctions and characterize them.

\section{Materials and Method}

A cross-sectional study was conducted at the Hospital das Clinicas of the Federal University of Pernambuco (Recife, Brazil) between May and October 2016. The study sample was composed of literate, sexually active pregnant women aged between 19 and 45 years, in a stable relationship. Multiparous women with clinical instability and psychiatric disorders were considered ineligible.

This study is in compliance with the Declaration of Helsinki and National Health Council guidelines (Resolution 466/2012) for research with human beings. It was approved by the Research Ethics Committee of Faculdade Estácio Recife under CAAE: 55494116-2-0000-5640.

All the patients were instructed as to the study objectives and methods and only those who agreed to participate by giving their informed consent were included. They were also advised that they would continue to be treated at the health facility regardless of their participation. 


\section{Journal of Complementary Medicine \& Alternative Healthcare}

Data were collected on a self-applied questionnaire composed of items related to socio demographic information (skin color, marital state, family income, schooling level, occupation), prepared and applied by previously trained researchers. The sexual function of the pregnant women was assessed at an interview during which the "Female Sexual Function Index (FSFI)", a reliable scale whose target population are women, was applied $[16,17]$. FSFI contains six sub-scales and a sum of the scores that measure the degree of desire, arousal, lubrication, orgasm, satisfaction and pain (dyspareunia). The scores of the subscales are added to produce a final score, ranging from 2 to 36 points, where the higher the value the better the sexual function. [18].

Data analysis was conducted using Statistical Package for Social Sciences (SPSS) 21.0 software. Descriptive analysis was carried out and expressed as frequencies, means and standard deviations. The Kolmogorov-Smirnov test was applied to verify the normal distribution of FSFI data. Once normality was established, one-way ANOVA with Tukey's post-hoc test was applied to compare the FSFI data of women in the first, second and third trimester of pregnancy. Furthermore, prevalence ratios (PR) and their respective confidence intervals were calculated to compare the existence of sexual dysfunctions between the trimesters. A significance level of 0.05 was adopted for all the analyses.

\section{Results}

Table 1: Distribution of pregnant women according to sociodemographic variables, Recife / PE - Brazil, 2016.

\begin{tabular}{|c|c|c|}
\hline Characteristics & Frequency $\mathbf{n}=101$ & Percentage (\%) \\
\hline Age (years) - Mean (SD) & $26.07(5.59)$ & \\
\hline Weight (kg) - Mean (SD) & $71.91(16.98)$ & \\
\hline \multicolumn{2}{|c|}{ Self-Declared Color } \\
\hline White & 25 & 24.8 \\
\hline Black & 21 & 20.8 \\
\hline Others & 55 & 54.5 \\
\hline \multicolumn{2}{|c|}{ Marital Status } \\
\hline Married & 33 & 32.7 \\
\hline Single & 32 & 31.7 \\
\hline Widower & 0 & 0.0 \\
\hline Divorced & 0 & 35.6 \\
\hline Consensual union & 36 & 0.0 \\
\hline \multicolumn{2}{|c|}{ Scholarity (Years) } \\
\hline None & 0 & 0.0 \\
\hline From 1 to 3 years & 0 & 14.9 \\
\hline From 4 to 7 years & 15 & 51.5 \\
\hline From 8 to 11 years & 52 & \\
\hline More than 12 years & 34 & \\
\hline
\end{tabular}

\begin{tabular}{|c|c|c|}
\hline \multicolumn{3}{|c|}{ Family Finance (MW) } \\
\hline Less than 1 & 7 & 6.9 \\
\hline From 1 to 2 & 71 & 70.3 \\
\hline From 3 to 4 & 19 & 18.8 \\
\hline More than 5 & 4 & 4.0 \\
\hline
\end{tabular}

${ }^{*} \mathrm{MW}$ : Minimum wage based on the value of the year $2016=\mathrm{R} \$ 880$ *SD: Standard Deviation.

\section{*SD: Standard Deviation.}

A total of 101 pregnant women were interviewed, with a mean age of 26.07 (5.59 SD) years and mean weight of 71.91 (16.98 SD) Kg Socio demographic variables are presented in Table 1, indicating that most (70.3\%) of the subjects earned an income between one and two minimum monthly wages (between USD 250.00 and 500.00) and they were in a stable relationship (35.6\%).

Table 2: Distribution of pregnant women according to obstetric characteristics, Recife / PE - Brazil, 2016.

\begin{tabular}{|c|c|c|}
\hline Characteristics & Frequency $n=101$ & Percentage (\%) \\
\hline \multicolumn{3}{|c|}{ Gestational Age } \\
\hline $1^{\text {st }}$ trimester & 13 & 12.9 \\
\hline $2^{\text {nd }}$ trimester & 34 & 33.6 \\
\hline $3^{\text {rd }}$ trimester & 54 & 53.5 \\
\hline \multicolumn{3}{|c|}{ Physical Activity } \\
\hline Practitioner & 19 & 18.8 \\
\hline Non-practitioner & 82 & 81.2 \\
\hline \multicolumn{3}{|c|}{ Planned Pregnancy } \\
\hline Yes & 35 & 34.7 \\
\hline No & 66 & 65.3 \\
\hline \multicolumn{3}{|c|}{ Number of Pregnancies } \\
\hline 1 to 2 & 87 & 86.1 \\
\hline More than 3 & 14 & 13.9 \\
\hline \multicolumn{3}{|c|}{ Number of Vaginal Deliveries } \\
\hline 0 to 2 & 98 & 97.0 \\
\hline More than 3 & 3 & 3.0 \\
\hline \multicolumn{3}{|c|}{ Number of Cesarean Deliveries } \\
\hline 0 to 2 & 101 & 100.0 \\
\hline More than 3 & 0.0 & 0.0 \\
\hline \multicolumn{3}{|c|}{ Pelvic Surgery } \\
\hline Yes & 22 & 21.8 \\
\hline No & 79 & 78.2 \\
\hline \multicolumn{3}{|c|}{ Pelvic Trauma } \\
\hline Yes & 16 & 15.8 \\
\hline No & 85 & 84.2 \\
\hline \multicolumn{3}{|c|}{ Sexual Violence } \\
\hline Yes & 2 & 2.0 \\
\hline No & 99 & 98.0 \\
\hline \multicolumn{3}{|c|}{ Pelvic Disease } \\
\hline Yes & 5 & 5.0 \\
\hline No & 96 & 95.0 \\
\hline
\end{tabular}


The obstetric characteristics are shown in Table 2. The sample was composed of 13 pregnant women in the first trimester, 34 in the second and 54 in the third, $65.3 \%$ of whom did not plan their pregnancy, $86.1 \%$ had one or two pregnancies and $78.2 \%$ had never undergone surgery.

Table 3: Scores by domain and total score of the women assessed by Female Sexual Function Index Questionnaire (FSFI), Recife / PE - Brazil, 2016.

\begin{tabular}{|c|c|c|c|c|c|c|}
\hline Sexual Variables & $\begin{array}{c}\text { FSFI score 1 } \\
\text { trimester Mean (SD) }\end{array}$ & $\begin{array}{c}\text { FSFI score 2 } \\
\text { trimesterMean (SD) }\end{array}$ & $\begin{array}{c}\text { FSFI score 3 } \\
\text { trimester Mean (SD) }\end{array}$ & p1 $^{\text {rd }}$ & $\begin{array}{c}\text { p-value* } \\
\text { p2 }\end{array}$ & p3 \\
\hline Desire & $2.72(1.37)$ & $3.33(1.16)$ & $3.35(1.47)$ & 0.358 & 0.294 & 0.997 \\
\hline Arousal & $2.44(1.10)$ & $2.62(1.20)$ & $3.09(1.48)$ & 0.909 & 0.271 & 0.262 \\
\hline Lubrication & $3.18(1.24)$ & $3.40(0.94)$ & $3.27(1.53)$ & 0.863 & 0.972 & 0.895 \\
\hline Orgasm & $2.70(1.30)$ & $3.32(1.09)$ & $3.02(1.46)$ & 0.337 & 0.716 & 0.575 \\
\hline Satisfaction & $1.93(1.30)$ & $2.07(1.08)$ & $2.30(1.52)$ & 0.953 & 0.662 & 0.716 \\
\hline Pain & $3.84(1.95)$ & $4.4(1.79)$ & $3.42(1.87)$ & 0.632 & 0.749 & 0.049 \\
\hline Total & $17(6.52)$ & $19.16(4.83)$ & $18.33(6.83)$ & 0.533 & 0.764 & 0.814 \\
\hline
\end{tabular}

*one-way ANOVA with Tukey's post-hoc test

${ }^{*} \mathrm{p} 1$ : $1^{\text {st }}$ trimester vs. $2^{\text {nd }}$ trimester

${ }^{*}$ p2: $1^{\text {st }}$ trimester vs. $3^{\text {rd }}$ trimester

* $p 3$ : $2^{\text {nd }}$ trimester vs. $3^{\text {rd }}$ trimester

*Female Sexual Function Index (FSFI)

With respect to sexual function (Table 3), 96\% of the sample had sexual dysfunction (FSFI score <26). The mean scores in the three trimesters of pregnancy showed that most women exhibited some degree of sexual dysfunction regardless of trimester. Moreover, during the first trimester the women were more likely to have dysfunctions in desire, arousal, orgasms and satisfaction, evidenced by their low score $(<3)$. Low scores were reported for arousal and satisfaction in the second trimester, and for satisfaction during the third trimester. Comparison between the FSFI values in the first, second and third trimester showed no differences, except for pain. Although there were no differences in values between the first semester and those of the second $(p=0.632)$ and third (0.749), the third trimester values were lower than those of the second $(\mathrm{p}=0.049)$.

Analyses of PR revealed that women in the first trimester of pregnancy are just as likely to exhibit some type of sexual dysfunction as those in the second (PR $=0.95 \mid 95 \%$ CI: 0.81 to 1.11 ) and third trimester (PR=0.96 | 95\% CI: 0.82-1.12). Similarly, women in the second trimester have the same chance of having some sexual dysfunction (PR $=1.007$ | 95\% CI: 0.93 to 1.08).

\section{Discussion}

The present study involved 13 pregnant women in the first trimester of pregnancy, 34 in the second and 54 in the third, with mean age of 26.7 (5.59 SD) years, $35.6 \%$ in a stable relationship, $42.6 \%$ were unemployed and $81.2 \%$ did not engage in any physical activity. Mean total FSFI scores were lower than 26 points, indicating the presence of sexual dysfunction in most of the pregnant women in the sample (96\%), irrespective of trimester. Furthermore, the prevalence ratios showed the same likelihood of women in the first, second and third trimester of pregnancy displaying some type of sexual dysfunction.

During the first trimester, there were dysfunctions in desire, arousal, orgasm and satisfaction, in the second arousal and satisfaction and in the third, only satisfaction. Moreover, no differences were found when FSFI data were compared in the first, second and third trimester, except for pain, which exhibited lower values in the third trimester when compared to the second. However, the difference observed in the values obtained in the pain subscale seems not to be clinically relevant, given that the measures observed were relatively high for only one domain.

The fact that the women in this study displayed dysfunction in the phases of sexual desire and arousal was also reported in a cross-sectional study conducted in 2015 by Bezerra et al, involving 207 pregnant women [19]. Desire is the first phase of sexual response, and considered an essential factor for an individual's sexuality, since it influences the rest of the cycle. In the first trimester of pregnancy, women suffer from a series of psychological and sentimental conflicts, given that they are undergoing constant transformations [19]. The presence of symptoms such as malaise, sleepiness, fatigue, mood swings and changes in self-esteem, in addition to factors such as alcohol consumption, medication, circulating estrogen level or an increase in prolactin levels, possibly compromising desire and consequently affecting the phases of arousal, orgasm and sexual satisfaction $[14,19,20]$.

In relation to the arousal phase, dysfunctions may be related to vascular changes that occur during pregnancy and decrease vaginal and clitoral blood flow, as well as changes in muscle tone and diabetes, physical changes that may affect attractiveness or interfere in the desire phase [21]. Most of the women interviewed $(81.2 \%)$ reported not being practicing of 


\section{Journal of Complementary Medicine \& Alternative Healthcare}

physical activities, which may favor an increase in complaints related to desire and arousal, since exercise provides benefits by releasing endogenous opioids, which have a calming effect and improve mood, in addition to enhancing disposition, confidence and recovery of self-esteem [22]. Orgasm is defined as the most intensely pleasurable sexual sensation. Disorders during the orgasm phase may be caused by relationship problems, depression, unpleasant sexual experiences, inefficient sexual techniques, excessive anxiety and disorders in prior sexual response phases, which may prevent orgasm from occurring [21]. The influence of disturbances in the sexual phases before orgasm is suggested, given that the women who obtained lower scores also scored poorly in the desire and arousal phases.

In this respect, satisfaction is a factor that depends on all the earlier phases of sexual response and may be affected by particularities of the female organism related to the physiological changes that occur in the first, second or third trimester of pregnancy [23]. Moreover, during the entire pregnancy, women are influenced by psychosocial factors, such as those related to the baby, or religious and cultural aspects. In a study conducted by Kücükdurmaz with 207 pregnant women, it was reported that the most frequent fears of the pregnant women were related to the baby's health, such as miscarriage or premature delivery. In this respect, women may lose interest in sex and this could affect their sexual satisfaction [14]. Subject to numerous influences, the FSFI satisfaction scores of the women in the present study were low, regardless of the trimester. However, the information collected was not sufficient to conduct a deeper analysis of the reason for the low satisfaction values observed.

It is important to underscore that most of the women earned one to two minimum monthly wages $(70.3 \%)$ and had between 8 and 11 years of schooling (51.5\%). As such, low income and schooling levels may trigger physical and emotional stress, characteristic of the Brazilian population, which endures precarious health and education services $[11,23]$. Thus, the fact that pregnancy exacerbates emotions and increases physical strain, may lead to compromised sexual function in pregnant women [14].

Most of the pregnant women interviewed reported not having undergone previous pelvic surgery $(78.2 \%)$ or pelvic trauma (84.2\%). This characteristic, associated with scores that show little interference in the lubrication phase during the three trimesters, may have contributed to low predominance of pain in the study sample, regardless of the period of pregnancy and despite the difference found between the second and third trimester [24,25].

Among study limitations was FSFI application using an interview, since questions were related to sexual life, prompting participants to give more socially accepted responses, to avoid possible embarrassment. Furthermore, during results analysis, no sample calculation was made and there was a significant difference in the number of women in the first, second and third trimester of pregnancy.

\section{Conclusion}

Most of the pregnant women who took part in the present study displayed some degree of sexual dysfunction, irrespective of trimester. In this respect, during the first trimester the FSFI domains most affected were desire, arousal, orgasm and sexual satisfaction, in the second arousal and satisfaction and in the third only satisfaction.

It is suggested that new studies be conducted with group size based on sampling calculations and aimed at determining the primary risk factors for developing sexual dysfunctions during pregnancy in order to create prevention strategies.

\section{References}

1. Savall ACR, Fernando AKM, Cardoso L (2008) Perfil Do Comportamento Sexual Na Gestação. Fisioter em Mov 21(2): 61-70.

2. Carteiro D, Sousa L, Caldeira S (2016) Clinical indicators of sexual dysfunction in pregnant women: integrative literature review. Rev Bras Enferm 69(1): 153-161.

3. Martins TM, Almeida Y (2011) Abordagem sobre a sexualidade durante a gestação. Perspect Amaz 2: 80-89.

4. Araújo NM, Salim NR, Gualda DMR, da Silva LCFP (2012) Body and sexuality during pregnancy. Rev da Esc Enferm 46(3): 552-558.

5. Escudero-rivas R, Carretero P, Caño Á, Cruz M, Florido J (2013) Modifications of sexual activity during uncomplicated pregnancy: A prospective investigation of Spanish women. 5(8): 1289-1294.

6. Serrano F Gravidez (2005) Parto E Puerpério. 16(3): 27-31.

7. Monterio R, Souza J, Padilha T (2013) Sexualidade na gestação: A vida sexual durante a gravidez. An do Conic-Semesp 1.

8. Baptista P (2008) Modalidades terapêuticas da fisioterapia no período gestacional.

9. Holanda J (2010) Fatores associados às disfunções sexuais em mulheres no período pós-parto.

10. Silva AI, Figueiredo B (2005) Sexualidade na gravidez e após o parto. Psiquiatr Clínica 25(3): 253-264.

11. Mathias A, Pitangui A, Arantes V, Freitas H, Vilela F, et al. (2015) Disfunção sexual: Avaliação de mulheres durante o terceiro trimestre gestacional. ABCS Heal Sci 40(2): 75-79.

12. Abdool Z, Thakar R, Sultan AH (2009) Postpartum female sexual function. Eur J Obstet Gynecol Reprod Biol 145(2): 133-137.

13. Eftekhar T, Sohrabi M, Haghollahi F, Shariat M, Miri E (2014) Comparison effect of physiotherapy with surgery on sexual function in patients with pelvic floor disorder: A randomized clinical trial. Iran J Reprod Med 12(1): 7-14.

14. Küçükdurmaz F, Efe E, Malkoç Ö, Kolus E, Amasyalı AS, et al. (2016) Prevalence and correlates of female sexual dysfunction among Turkish pregnant women. Turkish J Urol 42(3): 178-183.

15. Leite AP, Campos AA, Dias AR, Amed AM, De Souza E, et al. (2009) Prevalence of sexual dysfunction during pregnancy. Rev Assoc Med Bras 55(5): 563-568.

16. Sossah L (2014) Sexual Behavior During Pregnancy: A Descriptive Correlational Study Among Pregnant Women. Eur J Res Med Sci 2(1): 16-27. 
17. Wiegel M, Meston C, Rosen R (2005) The Female Sexual Function Index (FSFI): Cross-Validation and Development of Clinical Cutoff Scores. J Sex Marital Ther 31(1): 1-20.

18. Hentschel H, Alberton DL, Capp E, Goldim JR, Passos EP (2007) Validação do Female Sexual Function index (FSFI) para uso em língua portuguesa. Rev HCPA 27(1): 10-14.

19. Bezerra IFD, de Sousa VPS, dos Santos LC, Viana E de SR (2015) Comparação da qualidade de vida em gestantes com disfunção sexual. Rev Bras Ginecol e Obs 37(6): 266-271.

20. Prado DS, Lima RV, de Lima LM (2013) Impact of pregnancy on female sexual function. Rev Bras Ginecol Obstet 35(5): 205-209.

21. Antonioli RS, Simões D (2010) Abordagem fisioterapêutica nas disfunções sexuais femininas. Rev Neurociencias 18(2): 267-274.
22. Cabral PU, Canário AC, Spyrides MH, Uchôa SA, Júnior JE, et al. Physical activity and sexual function in middle-aged women. Rev Assoc Med Bras 60(1): 47-52.

23. Naldoni LMV, Pazmiño MA, Pezzan PA, Pereira SB, Duarte G, et al. (2011) Evaluation of sexual function in Brazilian pregnant women. J Sex Marital Ther 37(2): 116-129.

24. Ferreira A, Souza A, Amorim M (2007) Prevalência das disfunções sexuais femininas em clínica de planejamento familiar de um hospital escola no Recife, Pernambuco. Rev Bras Saúde Matern Infant Recife $7(2): 143-150$.

25. Cabral PUL, Canário ACG, Spyrides MHC, Uchôa SADC, Eleutério Júnior J, et al. (2012) Influência dos sintomas climatéricos sobre a função sexual de mulheres de meia-idade. Rev Bras Ginecol e Obs. 34(7): 329 334.

\section{Your next submission with Juniper Publishers will reach you the below assets}

- Quality Editorial service

- Swift Peer Review

- Reprints availability

- E-prints Service

- Manuscript Podcast for convenient understanding

- Global attainment for your research

- Manuscript accessibility in different formats

( Pdf, E-pub, Full Text, Audio)

- Unceasing customer service

Track the below URL for one-step submission https://juniperpublishers.com/online-submission.php 